WSRC-STI-2008-00352

Revision 1

\title{
SLUDGE BATCH 5 ACCEPTANCE EVALUATION: RADIONUCLIDE CONCENTRATIONS IN TANK 51 SB5 QUALIFICATION SAMPLE PREPARED AT SRNL
}

\author{
C. J. Bannochie \\ N. E. Bibler \\ D. P. DiPrete
}

September 2008

Environmental and Chemical Process Technology Research Programs Savannah River National Laboratory

Aiken, SC 29808

Prepared for the U.S. Department of Energy Under Contract Number DEAC09 96SR18500

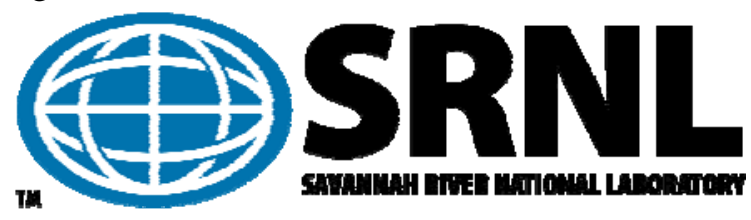




\section{DISCLAIMER}

This report was prepared by Washington Savannah River Company (WSRC) for the United States Department of Energy under Contract No. DE-AC09-96SR18500 and is an account of work performed under that contract. Neither the United States Department of Energy, nor WSRC, nor any of their employees makes any warranty, expressed or implied, or assumes any legal liability or responsibility for the accuracy, completeness, or usefulness, of any information, apparatus, or product or process disclosed herein or represents that its use will not infringe privately owned rights. Reference herein to any specific commercial product, process, or service by trademark, name, and manufacturer or otherwise does not necessarily constitute or imply endorsement, recommendation, or favoring of same by WSRC or by the United States Government or any agency thereof. The views and opinions of the authors expressed herein do not necessarily state or reflect those of the United States Government or any agency thereof.

\section{Printed in the United States of America}

Prepared For U.S. Department of Energy 
Key Words: DWPF, SB5 Qualification, Radionuclide

Retention: Permanent

\title{
SLUDGE BATCH 5 ACCEPTANCE EVALUATION: RADIONUCLIDE CONCENTRATIONS IN TANK 51 SB5 QUALIFICATION SAMPLE PREPARED AT SRNL
}

\author{
C. J. Bannochie \\ N. E. Bibler \\ D. P. DiPrete
}

September 2008

Environmental and Chemical Process Technology Research Programs Savannah River National Laboratory Aiken, SC 29808 


\section{AUTHOR(S):}

\section{TECHNICAL REVIEWER:}

\section{APPROVERS}

J. C. Griffin, Manager, Environmental \& Chemical Process Technology Research Programs Date 


\section{EXECUTIVE SUMMARY}

Presented in this report are radionuclide concentrations required as part of the program of qualifying Sludge Batch Five (SB5) for processing in the Defense Waste Processing Facility (DWPF). Part of this SB5 material is currently in Tank 51 being washed and prepared for transfer to Tank 40. The acceptance evaluation needs to be completed prior to the transfer of the material in Tank 51 to Tank 40 to complete the formation of SB5. The sludge slurry in Tank 40 has already been qualified for DWPF and is currently being processed as SB4. ${ }^{1}$ The radionuclide concentrations were measured or estimated in the Tank 51 SB5 Qualification Sample prepared at Savannah River National Laboratory (SRNL). This sample was prepared from the three liter sample of Tank 51 sludge slurry taken on March 21, 2008. The sample was delivered to SRNL where it was initially characterized in the Shielded Cells. ${ }^{2,3,4,5}$ Under direction of the Liquid Waste Organization it was then modified by five washes, six decants, an addition of $\mathrm{Pu} / \mathrm{Be}$ from Canyon Tank 16.4, and an addition of $\mathrm{NaNO}_{2}$. This final slurry now has a composition expected to be similar to that of the slurry in Tank 51 after final preparations have been made for transfer of that slurry to Tank 40.

Determining the radionuclide concentrations in this Tank 51 SB5 Qualification Sample is part of the work requested in Technical Task Request (TTR) No. HLW-DWPF-TTR-2008-0010. ${ }^{6}$ The work with this qualification sample is covered by a Task Technical and Quality Assurance Plan ${ }^{7}$ and an Analytical Study Plan $^{8}$. The radionuclides included in this report are needed for the DWPF Radiological Program Evaluation, the DWPF Waste Acceptance Criteria (TSR/WAC) Evaluation, and the DWPF Solid Waste Characterization Program (TTR Task 2). Radionuclides required to meet the Waste Acceptance Product Specifications (TTR Task 5) will be measured at a later date after the slurry from Tank 51 has been transferred to Tank 40. Then a sample of the as-processed SB5 will be taken and transferred to SRNL for measurement of these radionuclides.

Data presented in this report represents the measured or estimated radionuclide concentrations obtained from several standard and special analytical methods performed by Analytical Development (AD) personnel within SRNL. The method for I-129 measurement in sludge is described in detail. Most of these methods were performed on solutions resulting from the dissolutions of the slurry samples. Concentrations are given for twenty-nine radionuclides along with total alpha and beta activity. Values for total gamma and total gamma plus beta activities are also calculated. Results also indicate that $98 \%$ of the Tc-99 and 92\% of the I-129 that could have been in this sludge batch have been removed by chemical processing steps in the SRS Canyons or Tank Farm.

1. $\quad$ Pareizs, J. M., Bannochie, C. J., Barnes, M. J., Bibler, N. E., Click, D. R., Hansen, E. K., Lambert, D. P., and Stone, M. E., Demonstration of the DWPF Flowsheet in the SRNL Shielded Cells in Support of Sludge Batch 4 Qualification, WSRC-STI-2007-00053, Savannah River Site, Aiken, SC 29808 (2007).

2. Pareizs, J. M. and Bannochie, C. J., Initial Analyses of the Tank 51 Sludge Batch 5 Qualification Sample, SRNL-PSE-2008-00069, Savannah River Site, Aiken, SC 29808 (2008).

3. Stone, M. E., Initial Analysis of Total Base and Free Hydroxide on Tank 51 Sludge Batch Qualification Sample, SRNL-PSE-2008-00072, Savannah River Site, Aiken, SC 29808 (2008).

4. Bannochie, C. J., Ajo, H. M., Click, D. R., and Pareizs, J. M., Tank 51 SB5 Qualification Sample Elemental Slurry Composition, SRNL-PSE-2008-00087, Savannah River Site, Aiken, SC 29808 (2008).

5. Bannochie, C. J., Tank 51 SB5 Qualification Sample Elemental Supernate Composition, SRNL-PSE-200800097, Savannah River Site, Aiken, SC 29808 (2008).

6. Davis, B. A., Technical Task Request: Sludge Batch 5 SRNL Shielded Cells Testing, HLW-DWPF-TTR-20080010, Rev. 0, Savannah River Site, Aiken, SC 29808 (2008).

7. Bannochie, C. J. and Pareizs, J. M., Qualification of DWPF Sludge Batch 5 in the SRNL Shielded Cells: Task Technical and Quality Assurance Plan, WSRC-RP-2008-00137, Savannah River Site, Aiken SC (2008).

8. Bannochie, C. J. and Pareizs, J. M., Qualification of DWPF Sludge Batch 5 in the SRNL Shielded Cells: Analytical Study Plan, WSRC-RP-2008-00138, Savannah River Site, Aiken, SC 29808 (2008). 


\section{TABLE OF CONTENTS}

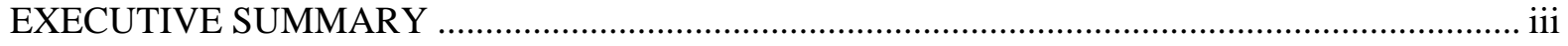

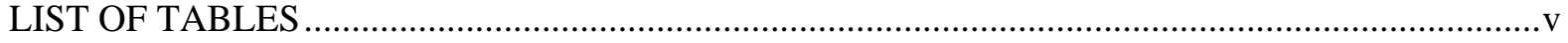

LIST OF ACRONYMS ............................................................................................................

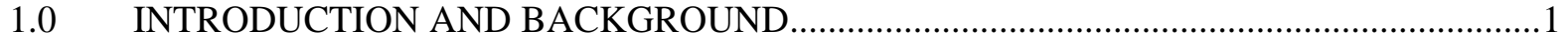

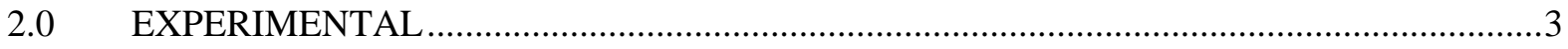

3.0 RADIONUCLIDE CONCENTRATIONS .....................................................................

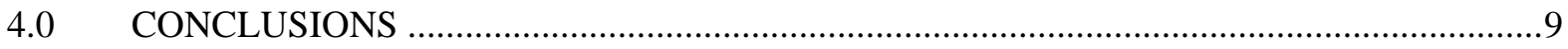

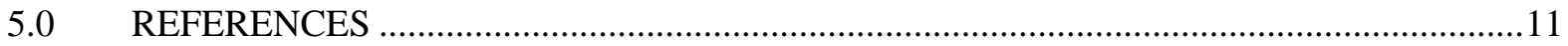

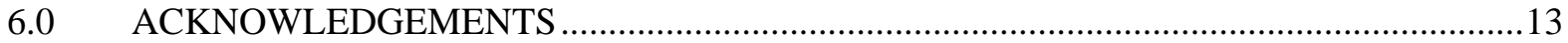


WSRC-STI-2008-00352

Revision 1

\section{LIST OF TABLES}

Table 2-1. Weight Percent Solids and Density for Washed Tank 51 SB5 Samples .............................3

Table 3-1. Concentrations of Radionuclides in the Tank 51 SB5 Qualification Sample Prepared at

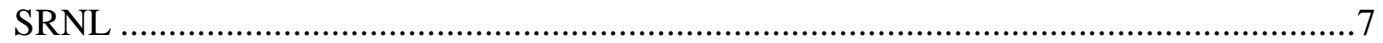




\section{LIST OF ACRONYMS}

$\begin{array}{ll}\text { AD } & \text { Analytical Development } \\ \text { ASP } & \text { Analytical Study Plan } \\ \text { DOE } & \text { Department of Energy } \\ \text { dpm } & \text { disintegrations per minute } \\ \text { DWPF } & \text { Defense Waste Processing Facility } \\ \text { g } & \text { gram } \\ \text { HTO } & \text { tritiated water } \\ \text { ICP-MS } & \text { Inductively Coupled Plasma - Mass Spectrometry } \\ \text { L } & \text { liter } \\ \mu \text { Ci } & \text { micro-Curies } \\ \text { QA } & \text { Quality Assurance } \\ \text { SB2 } & \text { Sludge Batch 2 } \\ \text { SB3 } & \text { Sludge Batch 3 } \\ \text { SB4 } & \text { Sludge Batch 4 } \\ \text { SB5 } & \text { Sludge Batch 5 } \\ \text { SpA } & \text { Specific Activity (Ci/g) } \\ \text { SRNL } & \text { Savannah River National Laboratory } \\ \text { SRS } & \text { Savannah River Site } \\ t_{1 / 2} & \text { half-life } \\ \text { TTQAP } & \text { Task Technical and Quality Assurance Plan } \\ \text { TTR } & \text { Task Technical Request } \\ \text { WAPS } & \text { Waste Acceptance Product Specifications } \\ \text { WCS } & \text { Waste Characterization System }\end{array}$




\subsection{INTRODUCTION AND BACKGROUND}

Presented in this report are radionuclide concentrations required as part of the program of qualifying Sludge Batch Five (SB5) for processing in the Defense Waste Processing Facility (DWPF). Part of this SB5 material is currently in Tank 51 being washed and prepared for transfer to Tank 40. The acceptance evaluation needs to be completed prior to the transfer of the material in Tank 51 to Tank 40 to complete the formation of SB5. The sludge slurry in Tank 40 has already been qualified for DWPF and is currently being processed as SB4. ${ }^{1}$ The radionuclide concentrations were measured or estimated in the Tank 51 SB5 Qualification Sample prepared at Savannah River National Laboratory (SRNL). This sample was prepared from the three liter sample of Tank 51 sludge slurry taken on March 21, 2008. The sample was delivered to SRNL where it was initially characterized in the Shielded Cells. ${ }^{2,3,4,5}$ Under direction of the Liquid Waste Organization it was then modified by five washes, six decants, an addition of $\mathrm{Pu} / \mathrm{Be}$ from Canyon Tank 16.4, and an addition of $\mathrm{NaNO}_{2}$. This final slurry now has a composition expected to be similar to that of the slurry in Tank 51 after final preparations have been made for transfer of that slurry to Tank 40.

Determining the radionuclide concentrations in this Tank 51 SB5 Qualification Sample is part of the work requested in Technical Task Request (TTR) No. HLW-DWPF-TTR-2008-0010. ${ }^{6}$ The work with this qualification sample is covered by a Task Technical and Quality Assurance Plan ${ }^{7}$ and an Analytical Study Plan. ${ }^{8}$ The radionuclides included in this report are needed for the DWPF Radiological Program Evaluation, the DWPF Waste Acceptance Criteria (TSR/WAC) Evaluation, and the DWPF Solid Waste Characterization Program (TTR Task 2). Radionuclides required to meet the Waste Acceptance Product Specifications (TTR Task 5) will be measured at a later date after the slurry from Tank 51 has been transferred to Tank 40. Then a sample of the as-processed SB5 will be taken and transferred to SRNL for measurement of these radionuclides. 
WSRC-STI-2008-00352

Revision 1

This page intentionally left blank. 


\subsection{EXPERIMENTAL}

Data presented in this report represents the measured or estimated radionuclide concentrations obtained from several standard analytical methods performed by Analytical Development (AD) personnel within SRNL. These methods were performed on solutions resulting from the dissolutions of the slurry samples. The dissolution methods were an alkali fusion ${ }^{9}$ and an aqua regia digestion ${ }^{10}$.

After the six decants/five washes, $\mathrm{Pu} / \mathrm{Be}$ stream addition, and $\mathrm{NaNO}_{2}$ addition, an aliquot of the 3-L Tank 51 sample was taken for analyses. The $\sim 200 \mathrm{~mL}$ aliquot taken for the radionuclide and other analyses was called Wash F slurry or SRAT Receipt Material and is the SB5 Qualification Sample prepared at SRNL. At that time, 1.18 liters of the Tank 51 Qualification Sample remained. All the measured radionuclides except Cs-137 are insoluble in caustic and are not removed from the slurry during washing.

Table 2-1 presents the weight percent solids and density measurements for the washed qualification sample prepared at SRNL, both sludge slurry (henceforth referred to as "slurry") and supernate.

Table 2-1. Weight Percent Solids and Density for Washed Tank 51 SB5 Samples

\begin{tabular}{cccccc}
\hline Sample Name & $\begin{array}{c}\text { Treatability Sample } \\
\text { ID }\end{array}$ & $\begin{array}{c}\text { Wt\% } \\
\text { Total } \\
\text { Solids } \\
{[\% \text { RSD] }}\end{array}$ & $\begin{array}{c}\text { Wt\% } \\
\text { Soluble } \\
\text { Solids } \\
{[\% \text { RSD] }}\end{array}$ & $\begin{array}{c}\text { Wt\% } \\
\text { Insoluble } \\
\text { Solids } \\
{[\% \text { RSD] }}\end{array}$ & $\begin{array}{c}\text { Density } \\
\text { (g/mL) } \\
{[\% \text { RSD] }}\end{array}$ \\
\hline Wash F Slurry & TS127-08-A-101640 & $\begin{array}{c}17.09 \\
{[0.2]}\end{array}$ & NA & 11.19 & 1.14 \\
& & & & {$[$ NA] } & {$[0.2]$} \\
Wash F Supernate & TS127-08-A-101639 & NA & 5.90 & NA & 1.06 \\
& & & {$[2.4]$} & & {$[0.4]$} \\
\hline
\end{tabular}

The experimental procedures for specific radionuclides will now be discussed. The concentration of tritium in the supernate of the sludge slurry was determined by using a sample of the supernate that had been separated from the insoluble solids by filtration. The tritiated water (HTO) and $\mathrm{H}_{2} \mathrm{O}$ were then distilled from four aliquots of the supernate. The $\mathrm{H}-3$ was determined by counting the beta particles from the HTO in the distillate of each aliquot. The H-3 concentration in the slurry was then calculated based on the density of the slurry, density of the supernate, and weight percent insoluble solids in the slurry.

The concentrations and upper limits reported are based on three or four replicate samples. Concentrations of H-3, Sr-90, and Pu-241 along with total beta activity are based on analyses by beta counting techniques. The concentrations of Co-60, Cs-137, Eu-154, Eu-155, and Am-241 were measured by gamma counting. The results for Tc-99, U-233, U-234, U-235, Np-237, U-238, Pu-239, and Pu-240 were determined by Inductively Coupled Plasma Mass Spectroscopy (ICP-MS) that measures the concentration of these radionuclides based on their masses rather than their radioactivity. These concentrations were converted to $\mu \mathrm{C} / \mathrm{g}$ using their specific activities ${ }^{11}$. The results for $\mathrm{Pu}-238$ and $\mathrm{Cm}-244$ along with the total alpha activity were measured by alpha counting. The concentrations of radionuclides Ru-106, Sb-125, Te-125m, Cs-134, Ce-144, and Pr-144 are reported as method detection limits due to their concentrations being too low to be detected because of their short half-lives and the age of the sludge. These limits were determined by gamma counting. The concentration for U-233 is also presented as a method detection limit because it was not detected by ICP-MS. The upper limit is based on the method detection limit for the ICP-MS analysis. 
The radionuclide Pm-147 is a short lived U-235 fission product that was measured. The methodology used to obtain the concentration of Pm-147 has been described previously ${ }^{12}$. A detection limit for the method is reported due to the low concentration in the aliquots measured.

The concentration reported for C-14 is estimated from its measured concentrations in Sludge Batch 2 (SB2), the projected concentrations in SB2 given in the Washington Savannah River Company Concentrate, Transfer, and Storage Characterization Database (WCS), and the projected concentrations given in WCS for the C-14 in the washed Tank 51 slurry prior to transferring it to Tank 40 . This is the method that was agreed upon in the TTP \& QA plan for SB5 qualification. ${ }^{7}$

The radionuclide I-129 is a long-lived beta emitting fission product $\left(\mathrm{t}_{1 / 2}=1.6 \mathrm{E}+07\right.$ years $)$ that is in SRS wastes. Two aliquots of wet sludge slurry were successfully spiked with a known amount of stable KI to act as an iodine tracer/carrier. The samples were digested with $8 \mathrm{M}$ nitric acid. The iodate/iodine in the samples was reduced with sodium sulfite to minimize losses of iodine in the Shielded Cells I-129 procedure. The Fe in the dissolutions was reduced to Fe (II) using ascorbic acid to ensure it would not interfere with subsequent decontamination steps designed to extract Y-90, the lanthanides, and the actinides from the KI traced dissolutions. The dissolutions were then treated with resins (Bio-Rad AMP1, Eichrom Sr, and Actinide resins) to reduce levels of Sr-90, Cs-137, Y-90, the lanthanides and the actinides. The resulting samples were then treated a second time with a sodium sulfite reduction and filtered. The samples were decontaminated a final time with a resin treatment (Eichrom $\mathrm{Sr}$ and RE resin cartridges) to ensure Sr-90/Y-90 levels were reduced low enough to allow for sample removal from the Shielded Cells and to remove Cs-137 and the actinide elements. The samples were then rendered caustic and filtered prior to removal from the Shielded Cells. The iodide remained soluble and was removed with the caustic filtrate. In $\mathrm{AD}$ the solution was treated with $\mathrm{AgNO}_{3}$ in order to precipitate the iodide ion as AgI. The precipitate was analyzed with a low energy semi planar high purity germanium detector. The $39 \mathrm{keV}$ gamma ray and 29 and $34 \mathrm{keV}$ X-rays characteristic to I-129 were clearly evident even though there was some slight background interference from low energy activities still present from Cs-137. Identical concentrations of I-129 were calculated based on both the $39 \mathrm{keV}$ gamma ray and the $29 \mathrm{keV} \mathrm{X}$ ray. Although it was detected, the $34 \mathrm{keV} \mathrm{X}$-ray was not resolved well enough to calculate a concentration for I-129. Final quantification was achieved by neutron activation of the iodine in the precipitate, via a Cf-252 neutron source at SRNL, to measure the total iodine present to calculate the recovery of total iodine from the separations process and determine the concentration I-129. 


\subsection{RADIONUCLIDE CONCENTRATIONS}

Table 3-1 presents the measured or estimated concentrations for twenty-nine individual radionuclides, the measured values for the total beta and total alpha activity along with the calculated values for total gamma and total beta plus gamma activities. The concentrations of those radionuclides that could not be measured due to their low concentrations have been estimated from minimum detection limits based on the analytical method used. For all the radionuclides except tritium (H-3), the concentrations are based on the total dried solids from dissolution of four replicates (two in the case of I-129) of the Tank 51 sludge slurry. Column 2 gives the concentrations in units of microcuries $(\mu \mathrm{Ci})$ per gram of total solids in the dried sludge slurry. Column 3 presents the relative percent standard deviations (\%RSD). Finally Column 4 presents the concentrations of the radionuclides in curies (Ci) per gallon of slurry calculated based on the measured weight percent total solids in the slurry (17.09 wt\%), the density of the slurry $(1.14 \mathrm{~g} / \mathrm{mL})$, and a conversion factor of $3785 \mathrm{~mL} /$ gal to convert to liquid gallons. Specific radionuclides will now be discussed.

Essentially all of the tritium in the Tank 51 slurry is present as tritiated water (HTO). Consequently, its concentration in the dried solids could not be determined because the HTO was evaporated during the drying of the slurry. The average concentration of $\mathrm{H}-3$ was $3.08 \times 10^{-5} \mathrm{Ci} /$ gal with a \%RSD of 3.3 based on four samples.

The radionuclides Y-90, Te-125m, and Ba-137m are in secular equilibrium with their respective parent radionuclides. Thus the activities of Y-90 and Te-125m are equal to that of their parents. Approximately $4 \%$ of the Cs-137 decays directly to stable Ba-137; thus the activity of Ba-137m is $96 \%$ of the activity of the Cs- 137.

The measured concentration for C-14 in SB2 was $8.10 \times 10^{-3} \mu \mathrm{Ci} / \mathrm{g} .{ }^{13}$ The projected concentration in SB2 was $1.40 \times 10^{-6} \mathrm{Ci} /$ gallon. ${ }^{14}$ The WCS projection for the total curies of C-14 in Tank 51 when the slurry is ready to be transferred to Tank 40 is $1.66 \times 10^{-1}$ curies. $^{15}$ The volume projected to be transferred to Tank 40 is $3.15 \times 10^{5}$ gallons. $^{15}$ The projected concentrations of C-14 is then $5.27 \times 10^{-7} \mathrm{Ci} / \mathrm{gallon}$. Multiplying the ratio of the projected concentrations in Tank 51 to the projected concentrations in SB2 by the measured concentrations in SB2 for each isotope gives $3.0 \times 10^{-3} \mu \mathrm{Ci} / \mathrm{g}$ for C-14.

The results for Tc-99 in the SB5 qualification sample are interesting in that they indicate that most of the Tc-99 that could have been in SB5 had been removed by the processing steps in the Canyons and Tank Farm of SRS. As shown below, it is estimated that 98\% of the Tc-99 that could have been in SB5 had been removed to the salt tanks or volatilized as a result of SRS canyon processing. This estimate is determined by comparing the maximum amount of Tc-99 that can be predicted to be in SB5 with the measured amount. The measured concentration in the total dried solids of the SB5 slurry was $1.14 \times 10^{-3}$ wt $\%$ as determined by ICP-MS analysis. This concentration times the specific activity of Tc-99 in Ci/g gives the activity concentration shown in Table 3-1. Estimation of the predicted amount will now be discussed. The fission products in SB5 were formed in the SRS reactors by thermal neutron fission of U235. Based on many experimental studies the relative yields of the fission products are known based on the number of atoms of each fission product isotope formed as a result of fission of 100 atoms of U-235. ${ }^{16}$ For a particular sludge batch, values for a fission yield scaling factor (FYSF) can be calculated from each measured concentration of a fission product. The FYSF is simply a proportionality factor that relates the concentration in wt\% of an isotope in the dried solids of sludge slurry to its fission yield and mass. For those isotopes that have six important properties, values for the FYSF will be equal for a sludge batch. These properties have been previously discussed. ${ }^{17}$ The following equation applies for each fission product. 


$$
\mathrm{FYSF}_{\mathrm{i}}=\times \mathrm{wt} \%_{\mathrm{i}} /\left(\mathrm{FY}_{\mathrm{i}} \times \mathrm{am}_{\mathrm{i}}\right)
$$

Where $\mathrm{FYSF}_{\mathrm{i}} \equiv$ the fission yield scaling factor based on isotope $\mathrm{wt}_{\mathrm{t}} \mathrm{o}_{\mathrm{i}} \equiv$ the weight percent of isotope $\mathrm{i}$ in the HLW total dried solids $\mathrm{FY}_{\mathrm{i}} \equiv$ the fission yield of isotope $\mathrm{i}$

$\mathrm{am}_{\mathrm{i}} \equiv$ the atomic mass of isotope $\mathrm{i}$

In SB5 there are 13 fission products that have the six important properties. These isotopes are: Ru-101, Ru-102, Rh-103, La-139, Ce-140, Pr-141, Ce-142, Nd-143 through Nd-146, Sm-147, and Nd-148. All of these isotopes were measured by ICP-MS in the total dried solids of the SB5 slurry. The average FYSF for SB5 calculated with these 13 isotopes is $9.40 \times 10^{-5}$ with a \%RSD of 7.8. After rearrangement of the above equation, the concentration of any fission product can be predicted. For Tc-99 with its half-life of $2.13 \times 10^{5}$ years and fission yield of $6.1 \%,{ }^{16}$ the predicted wt $\%$ for Tc-99 is $5.7 \times 10^{-2}$ wt\%. The measured value was $1.14 \times 10^{-3} \mathrm{wt} \%$, indicating that only $2 \%$ of the Tc-99 that could have been in this sludge batch was actually still in the sludge slurry. One of the main properties that a fission product must have to be retained in the sludge solids is that it is insoluble in caustic. If it were soluble in caustic it would not precipitate in the sludge solids and would be decanted or washed to the salt tanks in the Tank Farm. Technetium is known to form a pertechnetate anion that is soluble in caustic. ${ }^{17}$ This can explain the low concentration of Tc-99 in SB5. A previous study with SB3 also indicated a low concentration of Tc-99 in the sludge solids. ${ }^{17}$

The radionuclide I-129 is a U-235 fission product with a long half life of $1.6 \times 10^{7}$ years. Previously it has only been measured successfully in the Sludge Batch 4 (SB4) Waste Acceptance Product Specifications (WAPS) study where its concentration, based on three aliquots of sludge slurry, was reported. ${ }^{13}$ Other reported concentrations for previous sludge batches are based on the Waste Characterization System at SRS. For I-129 the average measured activity of I-129 in two aliquots of the sludge slurry was $9.13 \times 10^{-4} \mathrm{\mu Ci} / \mathrm{g}$ of total dried solids with a \%RSD of 8.0. Based on the success of the separations and counting results, this appears to be a reliable result. However, it was further checked by calculating the amount of I-129 that could be present using the FYSF. If this predicted concentration were less than the measured, then this would indicate that the measured number was erroneously high. Using the FYSF of $9.40 \times 10^{-5}$ and the fission yield for I-129 of $0.54 \%,{ }^{16}$ the predicted concentration of I129 in SB5 would be $6.5 \times 10^{-3} \mathrm{wt} \%$, assuming no I-129 were lost in processing. This concentration is $13 x$ higher than the measured value supporting the conclusion that the measured concentration is a reliable number. It also indicates that $92 \%$ of the I-129 was removed from SB5 by processing steps in the Canyons or Tank Farm. Likely steps are volatilization of iodine species during acid dissolution of irradiated targets or fuel assemblies in the Canyons or solubility of iodine species in caustic. 
Table 3-1. Concentrations of Radionuclides in the Tank 51 SB5 Qualification Sample Prepared at SRNL

\begin{tabular}{|c|c|c|c|}
\hline Radionuclide & $\begin{array}{c}\mu \mathrm{Ci} / \mathrm{g} \text { in Total } \\
\text { Dried Solids }\end{array}$ & \%RSD & $\begin{array}{c}\text { Ci/gal in Sludge } \\
\text { Slurry (a) }\end{array}$ \\
\hline H-3 & (b) & 3.3(b) & 3.08E-05 \\
\hline C-14 & $3.05 \mathrm{E}-03$ & N/A & 2.25E-06 \\
\hline Co-60 & $3.80 \mathrm{E}+00$ & 2.0 & $2.81 \mathrm{E}-03$ \\
\hline Sr-90 & $2.15 E+04$ & 11 & $1.59 \mathrm{E}+01$ \\
\hline$Y-90$ & $2.15 E+04$ & 11 & $1.59 \mathrm{E}+01$ \\
\hline Tc-99 & 1.93E-01 & 14 & 1.43E-04 \\
\hline Ru-106(c) & $<5.2 \mathrm{E}-01$ & N/A & $<3.8 \mathrm{E}-04$ \\
\hline Sb-125 & $<2.0 \mathrm{E}-01$ & N/A & $<1.5 \mathrm{E}-04$ \\
\hline Te-125m & $<2.0 \mathrm{E}-01$ & N/A & $<1.5 \mathrm{E}-04$ \\
\hline $\mathrm{I}-129$ & 9.13E-04 & 8.0 & 6.75E-07 \\
\hline Cs-134 & $<3.2 \mathrm{E}+00$ & N/A & $<2.4 \mathrm{E}-03$ \\
\hline Cs-137 & $4.06 \mathrm{E}+02$ & 3.1 & 3.00E-01 \\
\hline Ba-137m & $3.90 \mathrm{E}+02$ & 3.1 & 2.88E-01 \\
\hline Ce-144 & $<1.3 \mathrm{E}+00$ & N/A & $<9.6 \mathrm{E}-04$ \\
\hline Pr-144 & $<1.3 \mathrm{E}+00$ & N/A & $<9.6 \mathrm{E}-04$ \\
\hline Pm-147 & $<8.3 \mathrm{E}+01$ & N/A & $<6.2 \mathrm{E}-02$ \\
\hline Eu-154 & $3.09 E+01$ & 4.5 & 2.28E-02 \\
\hline Eu-155 & $3.57 \mathrm{E}+00$ & 11 & $2.85 \mathrm{E}-04$ \\
\hline $\mathrm{U}-233$ & $<9.6 \mathrm{E}-02$ & N/A & $<7.1 \mathrm{E}-05$ \\
\hline $\mathrm{U}-234$ & 7.89E-02 & 18 & 5.83E-05 \\
\hline $\mathrm{U}-235$ & 8.10E-04 & 2.6 & 5.99E-07 \\
\hline Np-237 & $1.78 \mathrm{E}-02$ & 4.7 & 1.31E-05 \\
\hline U-238 & $1.78 \mathrm{E}-02$ & 1.3 & $1.31 \mathrm{E}-05$ \\
\hline Pu-238 & $3.23 E+02$ & 2.6 & 2.39E-01 \\
\hline Pu-239 & $2.43 \mathrm{E}+01$ & 1.3 & $1.79 \mathrm{E}-02$ \\
\hline $\mathrm{Pu}-240$ & $8.65 \mathrm{E}+00$ & 5.3 & $6.40 \mathrm{E}-03$ \\
\hline Pu-241 & $<1.5 \mathrm{E}+02$ & N/A & $<1.1 \mathrm{E}-01$ \\
\hline Am-241 & $4.14 \mathrm{E}+01$ & 1.8 & 3.06E-02 \\
\hline Am-242m & $<6.6 \mathrm{E}-01$ & N/A & $<4.9 \mathrm{E}-04$ \\
\hline $\mathrm{Cm}-244$ & $3.10 \mathrm{E}+01$ & 4.6 & $2.29 \mathrm{E}-02$ \\
\hline $\mathrm{Cm}-245$ & $<8.9 \mathrm{E}-02$ & N/A & $<6.6 \mathrm{E}-05$ \\
\hline Total alpha & $4.74 \mathrm{E}+02$ & 1.8 & 3.51E-01 \\
\hline Total beta & $4.08 \mathrm{E}+04$ & 1.8 & $3.01 \mathrm{E}+01$ \\
\hline Total gamma(d) & $4.93 E+02$ & N/A & $3.62 \mathrm{E}-01$ \\
\hline Total beta-gamma & $4.13 E+04$ & N/A & $3.05 E+01$ \\
\hline
\end{tabular}

N/A = Not Applicable

(a) This was calculated for all the radionuclides except $\mathrm{H}-3$ using the weight percent total solids in the slurry of 17.09 and a slurry density of $1.14 \mathrm{~g} / \mathrm{mL}$.

(b) Most of the H-3 in the slurry is present as HTO; thus, drying the slurry sample would drive off most of the H-3. The concentration of H-3 was measured in four samples of the supernate of the Tank 51 SB5 sample slurry. The result was $8.53 \mathrm{E}-03 \mu \mathrm{Ci} / \mathrm{ml}$ with a \%RSD of 3.3. This was converted to $\mathrm{Ci} /$ gal slurry using $11.19 \mathrm{wt} \%$ insoluble solids in the slurry and the slurry and supernate densities.

(c) The total radioactivity in the slurry due to this radionuclide is twice this value because of the radioactive daughter, Rh-106, that is in secular equilibrium with this radionuclide and thus also present in the slurry.

(d) This assumes that each gamma emitter detected by gamma counting gives off only a single gamma ray. 
WSRC-STI-2008-00352

Revision 1

This page intentionally left blank. 


\subsection{CONCLUSIONS}

The results presented in this report are those necessary for DWPF to assess if the Tank 51 SB5 sample prepared at SRNL meets the requirements for the DWPF Radiological Program Evaluation, the DWPF Waste Acceptance Criteria evaluation, and the DWPF Solid Waste Characterization Program. Concentrations are given for twenty-nine radionuclides along with total alpha and beta activity. Values for total gamma and total gamma plus beta activities are also calculated.

Results also indicate that $98 \%$ of the Tc-99 and $92 \%$ of the I-129 that could have been in this sludge batch have been removed by chemical processing steps in the SRS Canyons or Tank Farm. 
WSRC-STI-2008-00352

Revision 1

This page intentionally left blank. 


\subsection{REFERENCES}

1. Pareizs, J. M., Bannochie, C. J., Barnes, M. J., Bibler, N. E., Click, D. R., Hansen, E. K., Lambert, D. P., and Stone, M. E., Demonstration of the DWPF Flowsheet in the SRNL Shielded Cells in Support of Sludge Batch 4 Qualification, WSRC-STI-2007-00053, Savannah River Site, Aiken, SC 29808 (2007).

2. Pareizs, J. M. and Bannochie, C. J., Initial Analyses of the Tank 51 Sludge Batch 5 Qualification Sample, SRNL-PSE-2008-00069, Savannah River Site, Aiken, SC 29808 (2008).

3. Stone, M. E., Initial Analysis of Total Base and Free Hydroxide on Tank 51 Sludge Batch Qualification Sample, SRNL-PSE-2008-00072, Savannah River Site, Aiken, SC 29808 (2008).

4. Bannochie, C. J., Ajo, H. M., Click, D. R., and Pareizs, J. M., Tank 51 SB5 Qualification Sample Elemental Slurry Composition, SRNL-PSE-2008-00087, Savannah River Site, Aiken, SC 29808 (2008).

5. Bannochie, C. J., Tank 51 SB5 Qualification Sample Elemental Supernate Composition, SRNL-PSE2008-00097, Savannah River Site, Aiken, SC 29808 (2008).

6. Davis, B. A., Technical Task Request: Sludge Batch 5 SRNL Shielded Cells Testing, HLW-DWPFTTR-2008-0010, Rev. 0, Savannah River Site, Aiken, SC 29808 (2008).

7. Bannochie, C. J. and Pareizs, J. M., Qualification of DWPF Sludge Batch 5 in the SRNL Shielded Cells: Task Technical and Quality Assurance Plan, WSRC-RP-2008-00137, Savannah River Site, Aiken SC (2008).

8. Bannochie, C. J. and Pareizs, J. M., Qualification of DWPF Sludge Batch 5 in the SRNL Shielded Cells: Analytical Study Plan, WSRC-RP-2008-00138, Savannah River Site, Aiken, SC 29808 (2008).

9. Coleman, C. J., Alkali Fusion Dissolutions of Sludge and Glass for Elemental Analysis, Manual L16.1, Procedure ADS-2502, Rev. 6, Savannah River Site, Aiken, SC 29808 (2008).

10. Coleman, C. J., Aqua Regia Dissolution of Sludge for Elemental Analysis, Manual L16.1, Procedure ADS-2226, Rev. 6, Savannah River Site, Aiken, SC 29808 (2003).

11. Integrated Data Base Report - 1994: U.S. Spent Nuclear Fuel and Radioactive Waste Inventories, Projections, and Characteristics, DOE/RW-0006, Rev. 11, Oak Ridge National Laboratory, Oak Ridge, TN (1995).

12. Bannochie, C. J., Bibler, N. E., and DiPrete, D. P., Determination of Reportable Radionuclides for DWPF Sludge Batch 4 (Macrobatch 5), WSRC-STI-2008-00142, Savannah River Site, Aiken, SC 29808 (2008).

13. Bibler, N. E., DiPrete, D. P., and Harbour, J. R., Determination of Reportable Radionuclides for DWPF Sludge Batch 2 (Macro Batch 3) (U), WSRC-TR-2002-00255, Savannah River Site, Aiken, SC 29808 (2002). 
14. Bibler, N. E. and Bannochie, C. J., Sludge Batch 4 Acceptance Evaluation: Radionuclide Concentrations in Tank 51 SB4 Qualification Sample Prepared at SRNL, WSRC-STI-2006-00036, Savannah River Site, Aiken, SC 29808 (2006).

15. Elder, H. H. and Ray, J. W., Estimated Quantity of C-14 in Sludge Batch 5 Sludge Slurry, LWOWSE-2008-00142, Savannah River Site, Aiken, SC (2008).

16. Baum, E. M., Knox, H. D., and Miller, T. R., Nuclides and Isotopes (Chart of the Nuclides), $16^{\text {th }}$ Edition, KAPL, Inc. and Lockheed Martin, 2002.

17. Bibler, N. E., Fellinger, T. L., and Hobbs, D. T., Technetium-99 Behavior in Savannah River Site HLW Sludges During Waste Processing, WSRC-MS-2004-00614, Savannah River Site, Published as Paper No. 4 in Session 43 of WM’06 Proceedings, WM Symposium, Tucson, AZ, February 2006. 


\subsection{ACKNOWLEDGEMENTS}

The authors would like to acknowledge the support of the SRNL Shielded Cells technicians and supervision. Additionally, we would like to thank Analytical Development personnel Henry Ajo for performing the digestion methods, and Ceci DiPrete for counting analyses and helpful consultations. 


\section{Distribution:}

J. C. Griffin, 773-A

D. A. Crowley, 999-W

C. C. Herman, 999-W

A. B. Barnes, 999-W

B. J. Giddings, 786-5A

S. D. Fink, 773-A

D. J. McCabe, 773-42A

C. W. Gardner, 773-A

N. E. Bibler, 773-A

J. M. Pareizs, 773-A

S. H. Reboul, 773-42A

D. K. Peeler, 999-W

M. E. Stone, 999-W

D. P. Lambert, 999-W

J. E. Occhipinti, 704-S

D. C. Sherburne, 704-S

J. F. Iaukea, 704-30S

J. W. Ray, 704-S

R. T. McNew, 704-27S

B. A. Davis, 704-27S

T. L. Fellinger, 704-26S

J. M. Bricker, 704-27S

A. R. Shafer, 704-27S

H. H. Elder, 704-26S

H. B. Shah, 766-H

J. M. Gillam, 766-H

B.A. Hamm, 766-H

D. D. Larsen, 766-H

D. C. Bumgardner, 703-H

M. T. Keefer, 766-H

D. J. Martin, 703-H

T. J. Miller, 703-H 